\title{
Assessment of nitrogen losses through nitrous oxide from abattoir wastewater-irrigated soils
}

\author{
Raghupathi Matheyarasu $^{1}$ - Balaji Seshadri ${ }^{2,3} \cdot$ Nanthi S. Bolan $^{2,3} \cdot$ Ravi Naidu $^{2,3}$
}

Received: 19 March 2016 / Accepted: 8 August 2016/Published online: 24 August 2016

(C) The Author(s) 2016. This article is published with open access at Springerlink.com

\begin{abstract}
The land disposal of waste and wastewater is a major source of $\mathrm{N}_{2} \mathrm{O}$ emission. This is due to the presence of high concentrations of nitrogen $(\mathrm{N})$ and carbon in the waste. Abattoir wastewater contains $186 \mathrm{mg} / \mathrm{L}$ of $\mathrm{N}$ and $30.4 \mathrm{mg} / \mathrm{L}$ of $\mathrm{P}$. The equivalent of $3 \mathrm{~kg}$ of abattoir wastewater-irrigated soil was sieved and taken in a 4-L plastic container. Abattoir wastewater was used for irrigating the plants at the rates of 50 and $100 \%$ field capacity (FC). Four crop species were used with no crop serving as a control. Nitrous oxide emission was monitored using a closed chamber technique. The chamber was placed inside the plastic container, and $\mathrm{N}_{2} \mathrm{O}$ emission was measured for 7 days after the planting. A syringe and pre-evacuated vial were used for collecting the gas samples; a fresh and clean syringe was used each time to avoid crosscontamination. The collected gas samples were injected into a gas chromatography device immediately after each sampling to analyse the concentration of $\mathrm{N}_{2} \mathrm{O}$ from different treatments. The overall $\mathrm{N}_{2} \mathrm{O}$ emission was compared for all the crops under two different abattoir wastewater treatment rates (50 and $100 \% \mathrm{FC}$ ). Under $100 \% \mathrm{FC}$ (wastewater irrigation), among the four species grown in the abattoir wastewaterirrigated soil, Medicago sativa (23 mg/pot), Sinapis alba
\end{abstract}

Responsible editor: Zhihong Xu

Raghupathi Matheyarasu

matry020@mymail.unisa.edu.au

1 Future Industries Institute, University of South Australia, Mawson Lakes, Adelaide, South Australia 5095, Australia

2 Global Centre for Environmental Remediation, The University of Newcastle, Callaghan, Adelaide, New South Wales 2308, Australia

3 Cooperative Research Centre for Contamination Assessment and Remediation of the Environment, P.O. Box 486, Salisbury, Adelaide, South Australia 5106, Australia
(21 mg/pot), Zea mays (20 mg/pot) and Helianthus annuus (20 mg/pot) showed higher $\mathrm{N}_{2} \mathrm{O}$ emission compared to the $50 \%$ treatments-M. sativa $(17 \mathrm{mg} / \mathrm{pot})$, S. alba $(17 \mathrm{mg} /$ pot), Z. mays (18 mg/pot) and H. annuus $(18 \mathrm{mg} / \mathrm{pot})$. Similarly, pots with plants have shown $15 \%$ less emission than the pots without plants. Similar trends of $\mathrm{N}_{2} \mathrm{O}$ emission flux were observed between the irrigation period (4-week period) for $50 \% \mathrm{FC}$ and $100 \% \mathrm{FC}$. Under the $100 \% \mathrm{FC}$ loading rate treatments, the highest $\mathrm{N}_{2} \mathrm{O}$ emission was in the following order: week $1>$ week $4>$ week $3>$ week 2 . On the other hand, under the $50 \% \mathrm{FC}$ loading rate treatments, the highest $\mathrm{N}_{2} \mathrm{O}$ emission was recorded in the first few weeks and in the following order: week $1>$ week $2>$ week $3>$ week $>4$. Since $\mathrm{N}_{2} \mathrm{O}$ is a greenhouse gas with high global warming potential, its emission from wastewater irrigation is likely to impact global climate change. Therefore, it is important to examine the effects of abattoir wastewater irrigation on soil for $\mathrm{N}_{2} \mathrm{O}$ emission potential.

Keywords Abattoir · Wastewater · Irrigation · Nitrous oxide · Emission $\cdot$ Greenhouse gas and global warming

\section{Introduction}

The emission of greenhouse gases (GHGs) increases with the rising global population (Preston et al. 2006). Human activities such as agriculture (e.g. chemical fertilisers), energy production (e.g. coal combustion), transport (e.g. fossil fuels) and other industrial activities are directly or indirectly contributing to the GHG emissions (Crutzen et al. 2008). Among the various sources that are responsible for GHG emissions, energy production is the major contributor followed by land use change for agriculture and industrial activities (Meinshausen et al. 2009; Cerri et al. 2009). The major global greenhouse 
gases and their percentage of emission are illustrated in Fig. 1. At a global scale, nitrous oxide $\left(\mathrm{N}_{2} \mathrm{O}\right)$ is a major $\mathrm{GHG}$ after carbon dioxide $\left(\mathrm{CO}_{2}\right)$ and methane $\left(\mathrm{CH}_{4}\right)$ (IPCC-2007). However, the global warming potential (GWP) varies between these GHGs, for example, $\mathrm{N}_{2} \mathrm{O}$ is 282 times more powerful than $\mathrm{CO}_{2}$ (Ravishankara et al. 2009). Hence, the management of $\mathrm{N}_{2} \mathrm{O}$ by reducing their emission is important in mitigating climate change (McCarl and Schneider 2000). Since $\mathrm{N}_{2} \mathrm{O}$ is a highly potential GHG towards GWP, measurement and mitigation need to be done on a broader scale (Shine et al. 2005). $\mathrm{N}_{2} \mathrm{O}$ emission contributes about $6 \%$ of the overall global warming effect, but its contribution from the agricultural sector is about $16 \%$. Of that, almost $80 \%$ of $\mathrm{N}_{2} \mathrm{O}$ is emitted from Australian agricultural lands, originating from $\mathrm{N}$ fertilisers (32\%), soil disturbance $(38 \%)$ and animal waste $(30 \%)$ (Dalal et al. 2003).

Globally, denitrification is the primary process of $\mathrm{N}_{2} \mathrm{O}$ production in temperate grassland soils and accounts for $60 \%$ of the total $\mathrm{N}_{2} \mathrm{O}$ emissions (Jha et al. 2012). A recent study at the European Union states that ruminants (cows, sheep and goats) have the highest carbon footprint (FAO 2006). Total net GHG emission of EU livestock production was estimated at $661 \mathrm{mt}$ of carbon dioxide equivalent $\left(\mathrm{CO}_{2}\right.$-eq $)$ which is about 9-13\% of the total GHG emission for the EU agricultural sector, comprising $23 \% \mathrm{CH}_{4}, 24 \% \mathrm{~N}_{2} \mathrm{O}, 21 \% \mathrm{CO}_{2}$ (energy use) and $29 \% \mathrm{CO}_{2}$ (land use). A considerable amount of GHGs is emitted by the global animal industry, which is more than all the cars in the world put together, and a large part of that is $18 \% \mathrm{~N}_{2} \mathrm{O}$ and $\mathrm{CH}_{4}$ emissions; both of these gases have a far more powerful greenhouse gas effect than carbon dioxide (Garnaut et al. 2008).

The livestock sector accounts for 5-50\% of the total contribution, but it may vary from place to place (Gunnarsson et al. 2011). The overall contribution consists of pigs $0.4 \%$, sheep $3.4 \%$, cattle $2.7 \%$ and beef

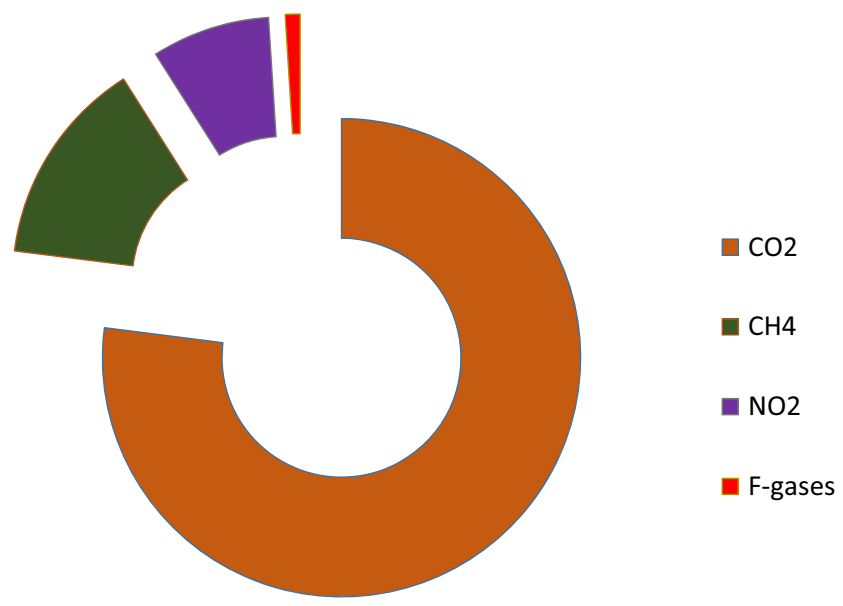

Fig. 1 Global greenhouse gases emission (in \%) (adapted from IPCC report 2007) (F-gases $=$ fluorinated gas (hydrofluorocarbons (HFCs), perfluorocarbons (PFCs), sulphur hexafluoride (SF6) and nitrogen trifluoride (NF3)] cattle $11.2 \%$, which on average emits $554 \mathrm{~kg} \mathrm{CO}$-eq/ tonne hot standard carcass weight (MLA 2010). Untreated abattoir wastewater is unsuitable for reuse or discharge into the receiving environment. It will cause serious environmental hazards in the receiving environment such as eutrophication, land degradation, nutrient leaching, groundwater contamination, greenhouse gas emission and effects on ecosystem value; hence, a proper reduction in pollutant levels in the prior stage is essential. In the recent years, meat production and consumption have been increasing considerably and predicted to peak in 2020 predominantly in Asia and the Pacific. Global per capita meat consumption is projected to increase from $32.9 \mathrm{~kg} / \mathrm{rwt}$ in 2011 to $35.4 \mathrm{~kg} / \mathrm{rwt}$ in 2020 (OECD-FAO 2011). Meat production is a considerable source of global GHG emission, emitting methane, nitrous oxide and carbon dioxide through various stages. GHGs are emitted by direct energy consumption and indirectly by feedstock production, herding, movement of animals, product transport, slaughtering, cleaning and dressing the animal product, waste and wastewater. The disposal of waste and wastewater to land is a major source of $\mathrm{N}_{2} \mathrm{O}$ emission (Oene et al. 2005; Bolan et al. 2004). $\mathrm{N}_{2} \mathrm{O}$ emission from wastewater-irrigated soils has been explored by many researchers (Bhandral et al. 2007; Saggar et al. 2004; Dalal et al. 2003).

Agricultural industry wastewater such as abattoir and dairy wastewaters are significant contributors towards $\mathrm{N}_{2} \mathrm{O}$ emissions (Kampschreur et al. 2007; Russell et al. 1993). This is due to the presence of the high concentration of $\mathrm{N}$ and carbon; for example, abattoir wastewater (AWW) contains 200 to $400 \mathrm{mg} / \mathrm{L}$ of $\mathrm{N}$ and $545 \mathrm{mg} / \mathrm{L}$ of dissolved organic carbon (Longhurst et al. 2000; Cassidy and Belia 2005; Matheyarasu et al. 2012). Tsujimoto (1994) observed that $\mathrm{N}$ loss through leaching and gaseous emissions increases with an increasing level of animal waste and wastewater application in soil. Soils are the major source of the greenhouse gas nitrous oxide $\left(\mathrm{N}_{2} \mathrm{O}\right)$ in our atmosphere.

The rate of denitrification in soils and the relative proportions of $\mathrm{NO}, \mathrm{N}_{2} \mathrm{O}$ and $\mathrm{N}_{2}$ produced are controlled by various factors, such as soil microorganisms, climatic factors and management practices. The availability of mineral $\mathrm{N}$ (both $\mathrm{NH}_{4}{ }^{+}$and $\mathrm{NO}_{3}{ }^{-}$) and labile $\mathrm{C}$, together with processes that affect reaction rates, such as temperature, $\mathrm{pH}$ and redox potential in soil microsites (Saggar et al. 2013). $\mathrm{N}_{2} \mathrm{O}$ can be produced by nitrifiers, denitrifiers and nitrifiers paradoxically denitrifying. Soil moisture conditions are sub-optimal for denitrification, nitrifier denitrification and the major contributor to $\mathrm{N}_{2} \mathrm{O}$ emission (Kool et al. 2011). The majority of studies indicate that a significant amount of $\mathrm{N}$ in waste and wastewater is lost as $\mathrm{N}_{2} \mathrm{O}$ emissions (Kampschreur et al. 2009; Czepiel et al. 1995; Bolan et al. 2004; Saggar et al. 2015). Since $\mathrm{N}_{2} \mathrm{O}$ is a 
potential greenhouse gas with very high GWP, even low emissions can cause serious effects (Shine et al. 2005). In addition, the application of chemical fertilisers alone contributes $46 \%$ of $\mathrm{N}_{2} \mathrm{O}$ emission from the agriculture sector (Baumert et al. 2005) and therefore minimising the usage of these fertilisers will also reduce the emission rate.

There are increased concerns about denitrification associated with the loss of $\mathrm{N}$ in the environment. Denitrification can be both detrimental and beneficial to the environment (Bolan et al. 2004). For example, $\mathrm{N}_{2} \mathrm{O}$, one of the gaseous products from denitrification, has possible deleterious effects on global warming (Bateman and Baggs 2005). The primary consideration for mitigating gaseous $\mathrm{N}$ emissions from arable land is to match the supply of mineral $\mathrm{N}$ (from fertiliser application, legumefixed N) to plant needs, although it is possible to achieve uniform application of $\mathrm{N}$ fertilisers. Mitigation approaches need to focus on ways to reduce the production of $\mathrm{N}_{2} \mathrm{O}$ during denitrification and enhance the reduction of $\mathrm{N}_{2} \mathrm{O}$ to $\mathrm{N}_{2}$ thus lowering the $\mathrm{N}_{2} \mathrm{O}: \mathrm{N}_{2}$ product ratio (Saggar et al. 2013). On the other hand, effective management practices help to minimise processes such as leaching, denitrification and $\mathrm{NH}_{3}{ }^{-}$volatilisation, all of which lead to the loss of plant-available $\mathrm{N}$ from the soil-plant system. These management practices include optimum $\mathrm{N}$ supply to pasture crops, proper animal residue management, controlled-release fertiliser and proper water management (Bolan et al. 2004).

Wastewater irrigation increased the concentration of major nutrients (N, P and $\mathrm{K}$ ) in soil (Matheyarasu et al. 2014). Although there was an increase in soil fertility, the potential for $\mathrm{N}$ losses through nitrate leaching and $\mathrm{N}_{2} \mathrm{O}$ emission is likely to be high. There is a great scope and need for reducing $\mathrm{N}_{2} \mathrm{O}$ emissions from various sources to the atmosphere (Ravishankara et al. 2009; McCarl and Schneider 2000). Currently, there are limited reports on $\mathrm{N}_{2} \mathrm{O}$ emission from AWW-irrigated soils or AWWirrigated cropping system in Australia. Therefore, it is important to examine the effects of AWW irrigation on the GHG emission potential. This paper examines the effect of different types of nutrient source (wastewater and urea) and irrigation intensity on biomass productivity of selected plant species and their $\mathrm{N}$ uptake efficiency and $\mathrm{N}_{2} \mathrm{O}$ emission under greenhouse conditions. The overall objective of the study is to examine the effects of AWW irrigation on $\mathrm{N}$ uptake and $\mathrm{N}_{2} \mathrm{O}$ emission in a calcareous soil. The specific objectives of the study included (a) to quantify $\mathrm{N}_{2} \mathrm{O}$ emission from agricultural soil treated with various soil moisture conditions and $\mathrm{N}$ supplements (urea and AWW), (b) to investigate the effects of AWW irrigation on $\mathrm{N}_{2} \mathrm{O}$ emission and (c) to study the rate of plantinduced denitrification in two different moisture gradients (50 and $100 \%$ FC) with and without plants.

\section{Materials and methods}

\section{Contaminated site assessment and soil sample collection}

The study area (sampling site) is situated at $89.7 \mathrm{~km}$ north of Adelaide, South Australia. The latitude and longitude of the study area are $34^{\circ} 8^{\prime} 26.60^{\prime \prime} \mathrm{S}$ and $138^{\circ} 11^{\prime} 7.35^{\prime \prime} \mathrm{E}$; the range is $749 \mathrm{~m}$ and the elevation of the treatment site is generally flat ranging from $13.5 \mathrm{~m}$ Australian height datum (AHD) to $14.5 \mathrm{~m}$ AHD. The region has mean annual rainfall of $287.3 \mathrm{~mm}$ and annual mean maximum temperature of $22.8^{\circ} \mathrm{C}$ and minimum temperature of $10.7^{\circ} \mathrm{C}$. Abattoir wastewater and soil under abattoir wastewater irrigation were collected from land treatment. The AWW-irrigated soil were collected, air-dried and sieved to $<2 \mathrm{~mm}$ for physiochemical characterisation. The site was under long-term wastewater irrigation to manage wastewater economically and was used for forage production, alternatively. The land treatment site (CI) has received around $385 \mathrm{~mm}$ of secondary treated effluent applied over the year at the rate of $32 \mathrm{~mm}$ per month.

The CI soil also received an additional $310 \mathrm{~mm}$ of water through rainfall, during the period (2012). In the study site, the rate of irrigation was not adjusted according to annual rainfall since it is intended for land treatment. The stored soil samples as collected from different locations and depths were analysed for $\mathrm{pH}$, electrical conductivity (EC), nitrogen $(\mathrm{N})$, phosphorus $(\mathrm{P})$, carbon $(\mathrm{C})$ and micro nutrients. Soil analyses were performed following standard methods as described in the Soil Chemical Methods-Australasia (Rayment and Lyons 2011) manual. Soil $\mathrm{pH}$ was measured in water using glass electrodes at a 1:5 soil to water ratio. Soil EC was also measured at the same time using an $\mathrm{EC}$ meter. Soil total $\mathrm{C}$ and total $\mathrm{N}$ were estimated by dry combustion on air-dry soil using a LECO 2000 CNS analyser (Sparling et al. 2006). Olsen P was estimated by soil extraction with sodium bicarbonate $(0.5 \mathrm{M}$ at $\mathrm{pH} 8.5)$ and measured by the molybdenum blue method (Olsen et al. 1954). Absorbance was measured at $882 \mathrm{~nm}$ in an Agilent UVvisible spectroscopy system (Germany), and the Olsen P concentration was calculated by preparing a calibration curve against the standards. The total $\mathrm{P}$ and micronutrients were determined using inductively coupled plasma-optical emission spectrometry (ICP-OES), with acid-digested soil samples (1:3 ratio of concentrated nitric-hydrochloric acid mixture/aqua regia) (Chen and Ma 2001). Similarly, available N (nitrate-N and ammonia-N) was measured using the SKALAR SANS system (analyser) with potassium chloride (2 M)-extracted soil samples (Luo et al. 2004).

\section{Plant growth experiment}

The plant growth experiment was conducted at the University of South Australia greenhouse using the contaminated soil collected from the land treatment sites. The wastewater used 
in this experiment was collected from the Primo abattoir at Port Wakefield, which was rich in major plant nutrients such as total nitrogen (TN) and total phosphorus (TP). Two sets of experiments were conducted to examine the effects of wastewater irrigation on $\mathrm{N}$ loss through gaseous emission $\left(\mathrm{N}_{2} \mathrm{O}\right)$. In experiment 1 , urea was used as a $\mathrm{N}$ source to study the gaseous emission from the soil. In experiment 2, AWW was used as $\mathrm{N}$ source and the effects of adding wastewater at different loading rates towards $\mathrm{N}_{2} \mathrm{O}$ gaseous emission were studied.

\section{Experiment 1 -a study on $\mathrm{N}_{2} \mathrm{O}$ emission without plants in a laboratory condition}

Experiment 1 comprised seven treatments with three replicates to study the effects of urea addition on gaseous emission $\left(\mathrm{N}_{2} \mathrm{O}\right)$. In this experiment, five different moisture levels were applied (e.g. 25, 50, 75, 100 and $120 \%$ FC) with two levels of nitrogen loading (500 and $1000 \mathrm{mg} / \mathrm{kg}$ of soil) to examine the $\mathrm{N}$ loss through gaseous emission.

\section{Experiment 2-gaseous emission with plants}

The equivalent of $3 \mathrm{~kg}$ of soil was sieved and taken in a 4-L plastic container. AWW was used for irrigation of the plants at the rates of 50 and $100 \%$ FC. Crop species including Helianthus annuus, Sinapis alba, Medicago sativa and Zea mays were used with no crop serving as a control. The entire experiment was carried out with three replications (Plate 1). Treatment details are as follows: 2 moisture levels $* 4+1$ control (no plant) $* 3$ replicates $(2 * 5 * 3=30)$.

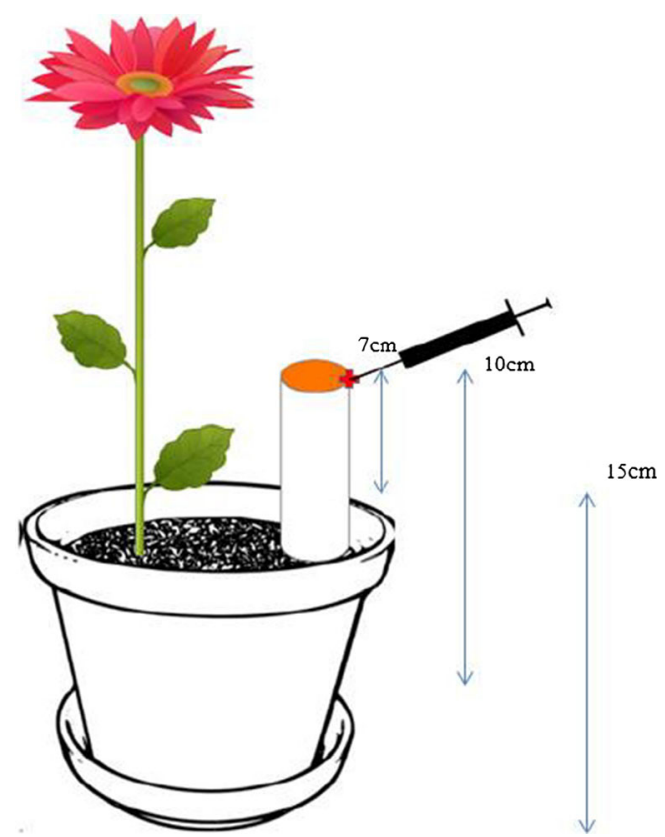

Plate 1 A study on plant-induced denitrification at a greenhouse located at the University of South Australia

\section{Gas sampling unit}

The $\mathrm{N}_{2} \mathrm{O}$ emission from the treatment pot was measured weekly using a modified closed chamber technique. The modified chamber technique was developed during this study based on the principles described by Saggar et al. (2002; 2004) and Bhandral et al. (2007). This modified closed chamber technique involves sampling of $\mathrm{N}_{2} \mathrm{O}$ emission close to the soil surface $(10 \mathrm{~cm})$, with the apparatus full description of the modified closed chamber presented in Fig. 2. The closed chamber was placed inside a pot (3 $\mathrm{kg}$ of soil). A total of 30 chambers were designed and used in this study with three replicates of each treatment. The dimensions of the chamber were $17 \mathrm{~cm}$ in height and $4 \mathrm{~cm}$ in diameter. The chamber was inserted into the soil with $7 \mathrm{~cm}$ exposed above the soil. Background $\mathrm{N}_{2} \mathrm{O}$ emissions were measured for each pot on the first day after the initial setup to validate and check the efficiency of the modified closed chamber. After the application of treatments, measurements were made every week until 4 weeks after planting.

\section{Gas sampling}

Each gas sampling unit was placed inside the pot (Plate 2). Emissions of $\mathrm{N}_{2} \mathrm{O}$ were measured for 7 days after the incubation in experiment 1 and planting in experiment 2 using the active efflux method. A syringe and pre-evacuated vials were used for collecting the gas samples; a fresh and clean syringe was used each time to avoid cross-contamination. The collected gas samples were injected to a gas chromatograph immediately after each sampling to analyse the emission of $\mathrm{N}_{2} \mathrm{O}$ from different treatments. At the end of the greenhouse studies, a nutrient loss percentage as $\mathrm{N}_{2} \mathrm{O}(\%)$ was calculated to study the nutrient losses using nutrient input and loss ratio.

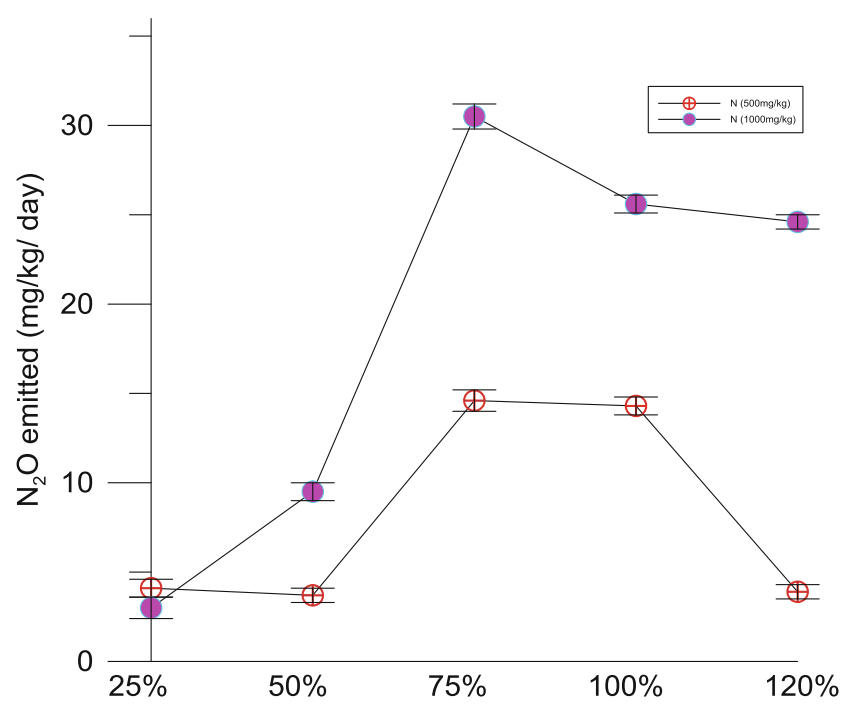

Fig. 2 Modified chamber techniques for the measurement of $\mathrm{N}_{2} \mathrm{O}$ emission from the controlled environment 
Plate 2 Gas sampling method for $\mathrm{N}_{2} \mathrm{O}$ analysis

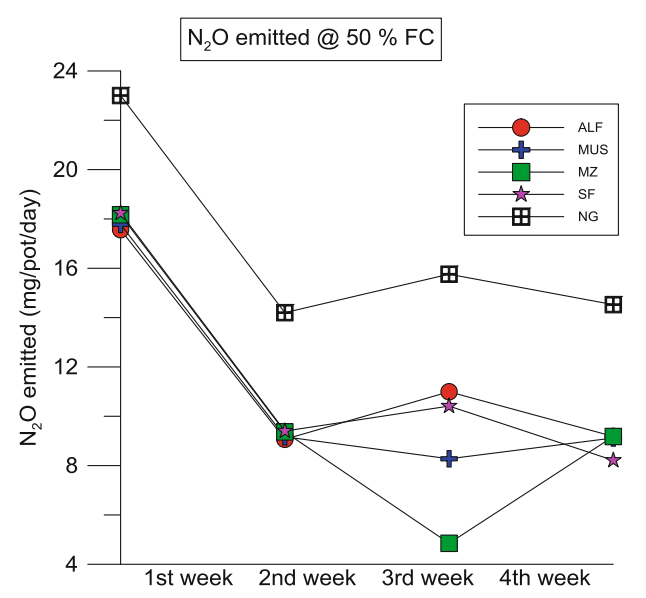

Plants were harvested after 6 weeks of germination. The shoots and roots were separated and dried in a hot air oven at $70{ }^{\circ} \mathrm{C}$ to a constant weight. Plant samples were stored in a dry airtight container for further nutrient analysis to calculate nutrient uptake.

\section{Statistical analysis}

SPSS (Inc., 2001) was used to analyse the data. The differences in the replicates were determined using standard deviations for the gaseous emission $\left(\mathrm{N}_{2} \mathrm{O}\right)$. Relationships between wastewater loading types (50 vs $100 \%$ FC) and gaseous emission $\left(\mathrm{N}_{2} \mathrm{O}\right)$ were analysed by Pearson correlation coefficients and the two-sample $t$ test.

\section{Results and discussion}

\section{Properties of soils and wastewater used in this experiment}

The soils used in this study were collected from an abattoir wastewater-discharged landfill site at Port Wakefield, South Australia. The collected samples were air-dried, characterised for physicochemical properties and used for greenhouse plant growth experiment (assessment of nitrogen losses). Soil collected from the land treatment site was moderately alkaline; the $\mathrm{pH}$ of the CI soil was moderately acidic (6.3), with CNI and CTRL measuring 8 and 8.6 , respectively. The electrical conductivity was very high ranging from 500 to $1109 \mu \mathrm{S} / \mathrm{cm}$.

The AWW-irrigated soil was high in TN and TP at available nutrient concentrations. The nutrient contents in AWWirrigated soil were up to $1165 \mathrm{mg} / \mathrm{kg}$ of nitrogen $(\mathrm{N})$ and $223 \mathrm{mg} / \mathrm{kg}$ of phosphorus (P). The wastewater sample was characterised for its major nutrient concentration ( $\mathrm{N}$ and $\mathrm{P}$ ) immediately after collection. The AWW used in this experiment had a high TN and TP concentration $(186 \mathrm{mg} / \mathrm{L}$ of $\mathrm{N}$ and $30.4 \mathrm{mg} / \mathrm{L}$ of P) (Table 1).

\section{Effects of urea application and rate of application} on nitrous oxide emission with varying soil moisture

The differences in the rate of $\mathrm{N}$ application (as urea) on $\mathrm{N}$ losses through $\mathrm{N}_{2} \mathrm{O}$ were observed by the end of the experiment. The application of urea with two different rates (low $=500 \mathrm{mg} / \mathrm{kg}$; high $=1000 \mathrm{mg} / \mathrm{kg}$ ) showed significant impacts on the $\mathrm{N}_{2} \mathrm{O}$ emission. The rate of emission was also significantly affected by the soil moisture content. The results showed that the high rate of $\mathrm{N}$ addition $(1000 \mathrm{mg} / \mathrm{kg}$ ) was most vulnerable in terms of $\mathrm{N}$ losses with varying moisture gradient. For both the levels of $\mathrm{N}$ application, the $\mathrm{N}_{2} \mathrm{O}$ emission increased with the increasing soil moisture content $(\%$ FC) up to the saturation (100\% FC) and the rate of $\mathrm{N}_{2} \mathrm{O}$ emission started to decline after the soil reaches the maximum water holding capacity ( $>100 \%$ FC).
Table 1 Properties of soil used in these experiments (wastewater-irrigated soil)

\begin{tabular}{ll}
\hline Soil parameters & Properties \\
\hline $\mathrm{pH}$ & $6.3 \pm 1.5$ \\
$\mathrm{EC}(\mu \mathrm{S} / \mathrm{cm})$ & $299.6 \pm 1.9$ \\
Moisture $(\%)$ & $11.8 \pm 0.1$ \\
Total C $(\mathrm{mg} / \mathrm{kg})$ & $10,523 \pm 1.1$ \\
Total N $(\mathrm{mg} / \mathrm{kg})$ & $1165.9 \pm 1.4$ \\
Nitrate-N $(\mathrm{mg} / \mathrm{kg})$ & $53.7 \pm 0.6$ \\
Ammonia-N $(\mathrm{mg} / \mathrm{kg})$ & $14.9 \pm 0.02$ \\
Total P $(\mathrm{mg} / \mathrm{kg})$ & $223.1 \pm 0.02$ \\
Olsen-P $(\mathrm{mg} / \mathrm{kg})$ & $73.6 \pm 0.08$ \\
$\mathrm{~K}(\mathrm{mg} / \mathrm{kg})$ & $2849.8 \pm 0.01$ \\
$\mathrm{Ca}(\mathrm{mg} / \mathrm{kg})$ & $2266.7 \pm 0.01$ \\
$\mathrm{Mg}(\mathrm{mg} / \mathrm{kg})$ & $709.2 \pm 0.09$ \\
$\mathrm{Na}(\mathrm{mg} / \mathrm{kg})$ & $308.9 \pm 0.05$ \\
$\mathrm{Fe}(\mathrm{mg} / \mathrm{kg})$ & $10.4 \pm 0.06$ \\
$\mathrm{Al}(\mathrm{mg} / \mathrm{kg})$ & $10.7 \pm 0.06$ \\
$\mathrm{~B}(\mathrm{mg} / \mathrm{kg})$ & $4.2 \pm 0.02$ \\
$\mathrm{Zn}(\mathrm{mg} / \mathrm{kg})$ & $0.4 \pm 0.03$ \\
$\mathrm{Mn}(\mathrm{mg} / \mathrm{kg})$ & $17.4 \pm 0.01$ \\
\hline
\end{tabular}


The rate of $\mathrm{N}_{2} \mathrm{O}$ emission will be minimum in a higher FC condition (waterlogged or flooded soils); this is due to less aeration (restricted) and low emission $\left(\mathrm{N}_{2} \mathrm{O}\right)$ leading to a complete denitrification process, thereby emitting $\mathrm{N}_{2}$ gas (Dalal et al. 2003). The maximum level of $\mathrm{N}_{2} \mathrm{O}$ emission was recorded at 75 to $100 \% \mathrm{FC}$ in both $\mathrm{N}$ treatment levels (500 and $1000 \mathrm{mg} / \mathrm{kg}$ of urea-N). Overall, high $\mathrm{N}$ addition with high soil moisture (75 to $100 \% \mathrm{FC}$ ) resulted in a significant amount of $\mathrm{N}$ losses which were about $30 \mathrm{mg} /$ pot/day emitted as $\mathrm{N}_{2} \mathrm{O}$. This was nearly twofold higher than that of the other treatment level of $500 \mathrm{mg} / \mathrm{kg}$ of soil $\mathrm{N}$ as urea (Fig. 3). Soil $\mathrm{N}_{2} \mathrm{O}$ production was highly dependent on the oxygen $\left(\mathrm{O}_{2}\right)$ supply and water-filled pore space (WFPS) (Bhandral et al. 2007; Dalal et al. 2003). The high $\mathrm{N}_{2} \mathrm{O}$ emission can be expressed in a situation like low $\mathrm{O}_{2}$ partial pressure $(<0.5$ vol. $\%)$ and high WFPS ( $>60 \%$ ) (Saggar et al. 2013). $\mathrm{N}_{2} \mathrm{O}$ is primarily produced in soil by the activities of microorganisms during nitrification and denitrification processes. The ratio of $\mathrm{N}_{2} \mathrm{O}$ production depends on oxygen supply or waterfilled pore space, decomposable organic carbon, $\mathrm{N}$ and substrate supply (Dalal et al. 2003).

\section{Effects of AWW irrigation on nitrous oxide emission}

\section{Effects of nutrient loading}

Abattoir wastewater is the major source of $\mathrm{N}$ to the soil. Irrigation of nutrient-rich AWW increased the soil fertility and nutrient loss, especially N. The soil nutrient loss was significantly higher under AWW irrigation compared to that in non-irrigated soils. The $\mathrm{N}_{2} \mathrm{O}$ emission rate significantly varied between the two levels of wastewater application. The distinct $\mathrm{N}_{2} \mathrm{O}$ peak was observed during the first week after the application of AWW in all the crop species grown and non-cropping condition. The peak was at $22 \mathrm{mg} /$ pot in $100 \% \mathrm{FC}$ and $18 \mathrm{mg} /$ pot in $50 \% \mathrm{FC}$ in non-cropped conditions (average of the initial period). According to Bowwman
(1996), up to $0.16 \%$ of total $\mathrm{N}$ applied to the soil can be lost as $\mathrm{N}_{2} \mathrm{O}$ emission within a day after fertiliser application (Dalal et al. 2003; Ruseel 1993). In comparison to all the treatments (including the AWW $50 \% \mathrm{FC}$ with and without a crop, AWW $100 \%$ FC with a crop), the AWW treatment without a crop showed statistically significant $\mathrm{N}_{2} \mathrm{O}$ emissions compared to the other treatment levels (Fig. 4). These increases were recorded from the first week after application of AWW. Similar results were found in Bhandral et al. (2007). They observed the peak emission of $\mathrm{N}_{2} \mathrm{O}$ from the meat industry wastewaterirrigated soils in the first few days after treatment.

The peak emission of $\mathrm{N}_{2} \mathrm{O}$ from the AWW $100 \% \mathrm{FC}$ (no crop) was $22 \%$ higher than that of the AWW $50 \%$ FC (no crop) which is $53 \%$ times higher than that of the cropped pot. A peak $\mathrm{N}_{2} \mathrm{O}$ emission flux of $21.9 \mathrm{mg} /$ pot/day was recorded under the non-cropping condition at the first week after planting; this indicates that there are greater chances for the loss of applied $\mathrm{N}$ if there is no crop to utilise the nutrients. According to Cardenas et al. (2010), high $\mathrm{N}$ input can increase the annual $\mathrm{N}_{2} \mathrm{O}$ emission fluxes in a pasture under a range of $\mathrm{N}$ fertiliser inputs and their study concluded that higher emissions are possible under increased nutrient supply. A significant increase was recorded in consecutive weeks, but the differences were not much significant as compared to the first week. The overall emission data of 4 weeks suggest that there were highly significant effects of a high load of nutrient addition through wastewater in terms of $\mathrm{N}$ loss.

\section{Effects of time}

The $\mathrm{N}_{2} \mathrm{O}$ emission was significant in $100 \% \mathrm{FC}$ at 2 weeks after the plantation in all the pots. The $\mathrm{N}_{2} \mathrm{O}$ emission was high at the first 2 weeks after the planting and declined subsequently to reach the background levels within 4 weeks. Application of AWW irrigation has increased the soil $\mathrm{N}_{2} \mathrm{O}$ emission rate in a short-duration study at the greenhouse for 4 weeks. The total emission in the first week was higher compared to that of the rest of the 3 weeks in both soils. The highest $\mathrm{N}_{2} \mathrm{O}$ emission
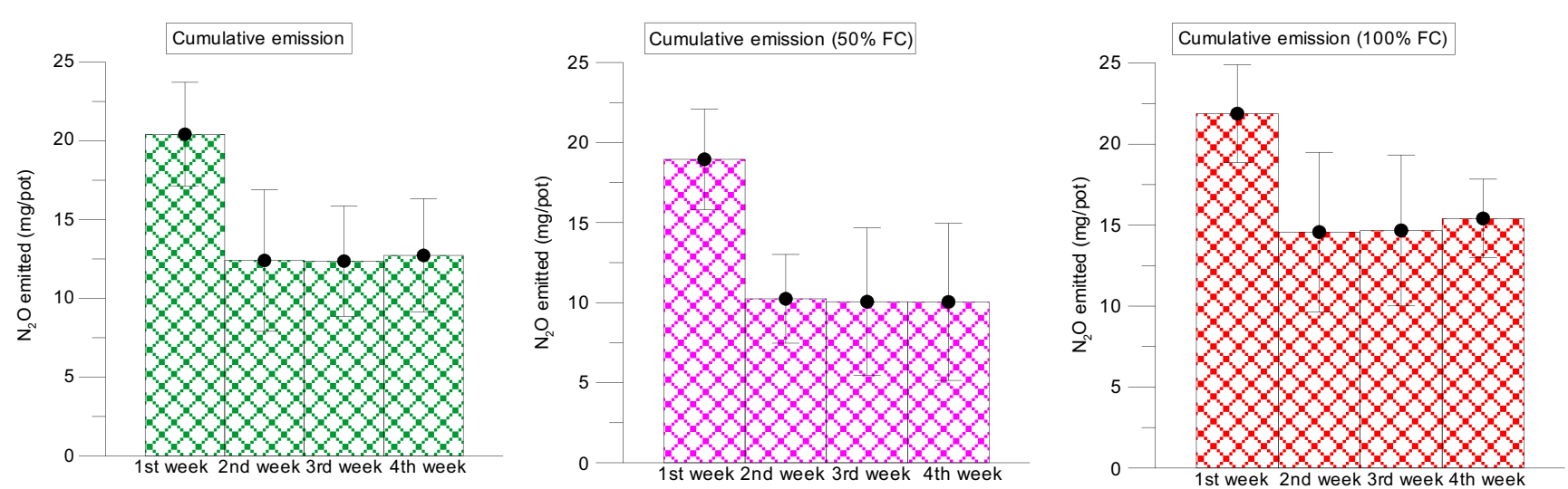

Fig. 3 Nitrous oxide emission from soil treated with urea with 500 and $1000 \mathrm{mg} / \mathrm{kg}$ - with varying moisture gradient $(25,50,75,100$ and $120 \%$ FC) 

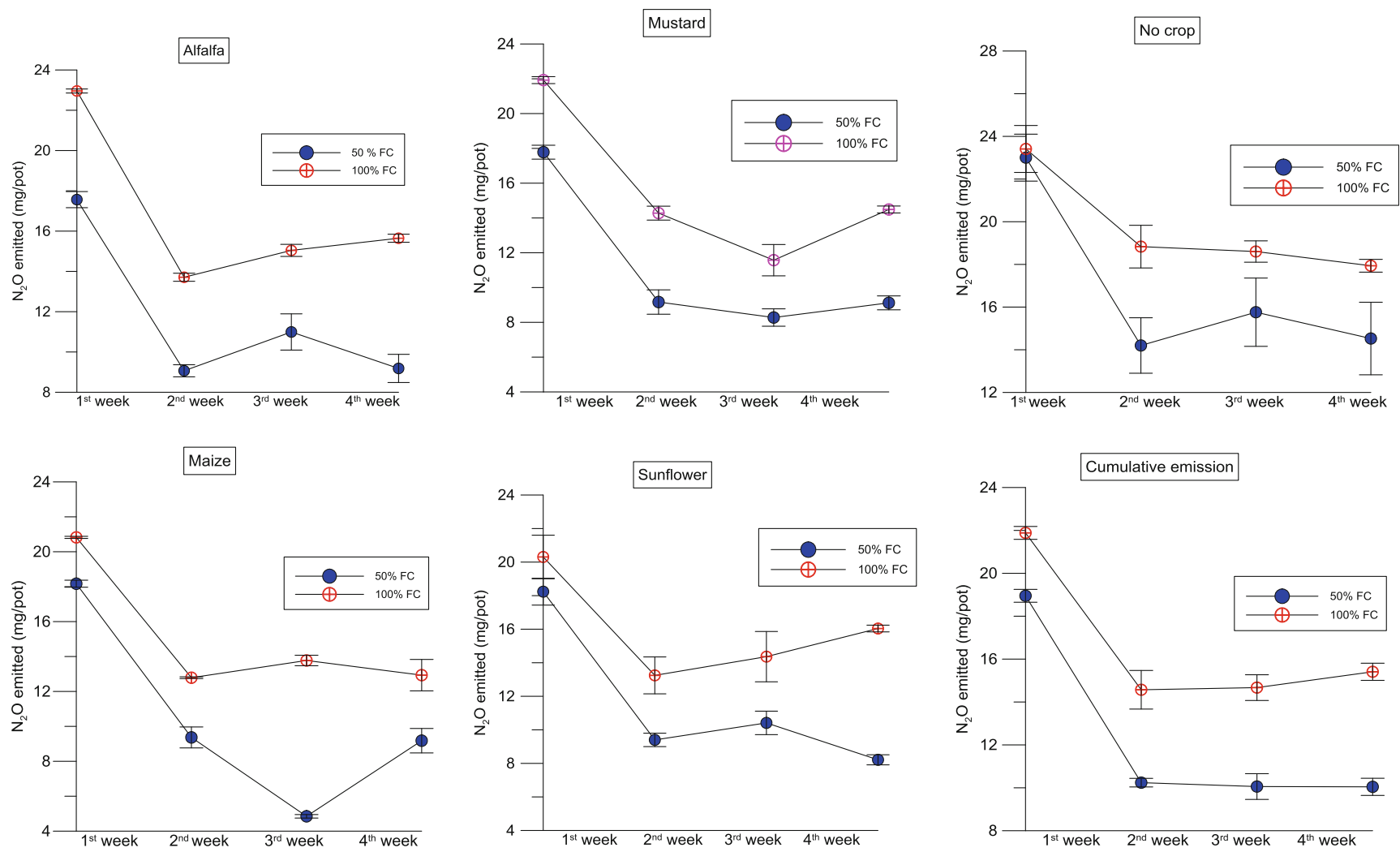

Fig. 4 Nitrous oxide emission from soil irrigated with abattoir wastewater with 50 and $100 \%$ FC (moisture gradients) -measured at 4 weeks after planting ( $A L F$ alfalfa, $M U$ mustard, $M Z$ maize, $S F$ sunflower, $N C$ no crop)

was recorded in the $100 \% \mathrm{FC}$ in the first week for all the four pots, which was about 21 to $22 \mathrm{mg} /$ pot. The AWW irrigation affected $\mathrm{N}_{2} \mathrm{O}$ emissions at both levels of irrigation (50 and $100 \% \mathrm{FC}$ ). The $\mathrm{N}_{2} \mathrm{O}$ emission increased initially (the first week after the treatment) and declined in the consecutive weeks of the experimental period (for example, the fourth week) (Fig. 5).

Application of AWW (at $100 \%$ FC) increased $\mathrm{N}_{2} \mathrm{O}$ emission by $8 \%$ in the first week and $43 \%$ in the second week after application. A similar study by Singh et al. (2008) states that the application of urine resulted in a high amount of $\mathrm{N}_{2} \mathrm{O}$ losses in their incubation studies. The authors found that the peak of $\mathrm{N}_{2} \mathrm{O}$ emissions was within a week after application of dairy cow urine and observed a maximum of $11.2 \mathrm{mg}$ of $\mathrm{N}_{2} \mathrm{O} /$ $\mathrm{kg}$ of soil. Also, their studies showed that the maximum emission was reached before day 25 of the 40-day incubation study (Singh et al. 2008). In the 4-week treatment period, $\mathrm{N}_{2} \mathrm{O}$ emissions from $100 \%$ FC (no crop) treatment in the first 2 weeks remained significantly higher than the $\mathrm{N}_{2} \mathrm{O}$ emitted from the $50 \%$ FC (no crop).

\section{Effects of plant species used}

There was a significant difference between AWW $50 \%$ FC and $100 \% \mathrm{FC}$ irrigation in the overall $\mathrm{N}_{2} \mathrm{O}$ emission of all the four crops used in this study. For example, in comparison with
$50 \%$ FC, 30, 23, 17 and $11 \%$ (H. annuus, S. alba, M. sativa and $Z$. mays) of increases in $\mathrm{N}$ loss were recorded as $\mathrm{N}_{2} \mathrm{O}$ in $100 \%$ FC. $\mathrm{N}_{2} \mathrm{O}$ emission was significantly $(p<0.05)$ higher in the application of $100 \%$ FC of AWW to all the four crops grown. A maximum of $27.5 \mathrm{mg} /$ pot was recorded in the $100 \%$ FC condition in the second week of application with AWW. In general, $\mathrm{N}_{2} \mathrm{O}$ emissions were significantly lower from all the crops irrigated with wastewater than those of the non-crop condition in both levels of treatment (50 and $100 \%$

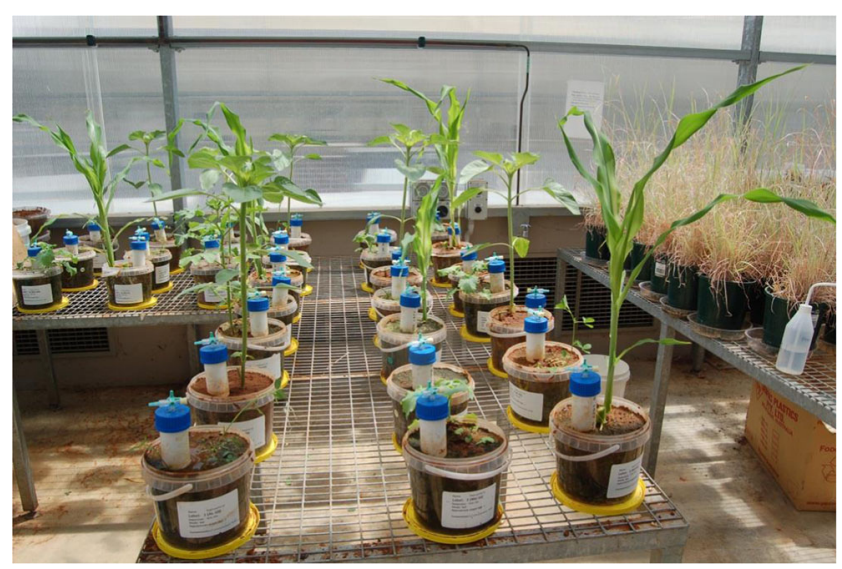

Fig. 5 The effects of abattoir wastewater (50 and $100 \%$ FC) on cumulative $\mathrm{N}_{2} \mathrm{O}$ emission of four plant species (alfalfa, mustard, maize and sunflower) measured at the fourth week after planting 
FC). The cumulative emissions recorded in the $50 \% \mathrm{FC}$ were $17.5,17.7,18.1$ and $18.2 \mathrm{mg} /$ pot for $H$. annuus, $S$. alba, $M$. sativa and $Z$. mays, respectively (non-cropped was $23 \mathrm{mg} /$ pot). Similarly, the cumulative emissions recorded in the $100 \%$ FC were 22, 21, 20 and $20 \mathrm{mg} /$ pot from $H$. annuus, $S$. alba, M. sativa and Z. mays, respectively (non-cropped was $23.4 \mathrm{mg} /$ pot) (Fig. 6). Pots with plants showed lower emissions than the pots without plants. Overall, the cumulative (average) $\mathrm{N}_{2} \mathrm{O}$ emission was $13 \%$ higher in high-fieldmoisture pots $(100 \% \mathrm{FC})$ than that in the moisture-deficit pots $\left(50 \%\right.$ FC) (Table 2). The second highest $\mathrm{N}_{2} \mathrm{O}$ emission was recorded on the second week after application of the AWW. A similar result was found in Bhandral et al. (2007), and they found that the initial increase in the $\mathrm{N}_{2} \mathrm{O}$ emission after the application of meat industry wastewater declined progressively with time.

\section{Effects of soil moisture}

Among the two levels of AWW irrigation treatment, $\mathrm{N}_{2} \mathrm{O}$ emissions were highest for AWW $100 \% \mathrm{FC}$ (16.6 mg/pot), whereas the $50 \%$ FC emitted $12.3 \mathrm{mg} /$ pot (cumulative emission average). Bhandral et al. (2007) suggested that the highest $\mathrm{N}_{2} \mathrm{O}$ emission is possible if soil is irrigated/applied with a high dose of urine, ammonium and urea.

The $\mathrm{N}_{2} \mathrm{O}$ emission was higher $(66.5 \mathrm{mg} /$ pot $)$ at $100 \% \mathrm{FC}$ $(p<0.01)$ than at $50 \% \mathrm{FC}(49 \mathrm{mg} / \mathrm{pot})$ which may be attributed to higher soil moisture content in the former treatment (Table 3). According to a study by Bateman and Baggs (2005), $\mathrm{N}_{2} \mathrm{O}$ emission was high under the elevated soil moisture condition. Soil $\mathrm{N}_{2} \mathrm{O}$ emission was significantly affected by soil moisture and a nutrient input source (Weier et al. 1993). Similarly, Maag and Vinther (1996) noticed that soil with an optimum moisture condition and high $\mathrm{N}$ source can produce increased $\mathrm{N}_{2} \mathrm{O}$ emissions. Results of decreased $\mathrm{N}_{2} \mathrm{O}$ production at low moisture content were obtained by Dalal et al. (2003). A study by Russel et al. (1993) on AWW irrigation to land treatment in a pastureland suggests that, under favourable conditions (e.g. a soil temperature below $12^{\circ} \mathrm{C}$, soil pH 5.9 and abattoir effluent $\mathrm{pH}$ of 5), $\mathrm{N}$ loss can reach a maximum within a day. Soil moisture was one of the most important factors influencing $\mathrm{N}_{2} \mathrm{O}$ emissions from tropical forest soils (Kiese and Butterbach-Bahl 2002). In moist soils, the reduction of $\mathrm{NO}_{3}{ }^{-}$proceeds in a series of steps, producing $\mathrm{NO}_{2}$, nitric oxide (NO), nitrous oxide $\left(\mathrm{N}_{2} \mathrm{O}\right)$ and $\mathrm{N}_{2}$ gas. Denitrification results not only in the loss of a valuable plant nutrient but also in the release of $\mathrm{N}_{2} \mathrm{O}$ (greenhouse gas), which is implicated in the destruction of atmospheric ozone (Bolan et al. 2004). In a flooded soil condition, denitrification has been considered to be a major pathway of $\mathrm{N}$ loss (Aulakh et al. 2001). Nitrifier denitrification can be a prime contributor to total $\mathrm{N}_{2} \mathrm{O}$ production from the soil. Nitrifier denitrification contributed more to $\mathrm{N}_{2} \mathrm{O}$ production than total conventional denitrification of $\mathrm{NO}_{3}^{-}$at both 50 and $70 \%$ WFPS.

\section{Statistical significance}

The overall emissions of $\mathrm{N}_{2} \mathrm{O}$ were positively correlated with nitrate- $\mathrm{N}$ and ammonia- $\mathrm{N}$ for all the 4 weeks of treatment, but the $\mathrm{N}_{2} \mathrm{O}$ emission was negatively correlated with plant DM yield. This means that high plant growth can minimise the $\mathrm{N}$ loss as $\mathrm{N}_{2} \mathrm{O}$ emission as a result of elevated $\mathrm{N}$ uptake. Similar to soil moisture content, $\mathrm{N}_{2} \mathrm{O}$ emission was positively correlated with ammonia-N, pH and Olsen P (Jha et al. 2012). In the current study, the soil was collected from the land treatment site (AWW irrigated) which was rich in soil nutrients such as nitrate-N, ammonia-N and Olsen P. Overall, the plots irrigated with AWW $100 \%$ FC showed significantly higher $\mathrm{N}$ loss $\left(\mathrm{N}_{2} \mathrm{O}\right)$ than the plots irrigated with $50 \% \mathrm{FC}$ for all four plant species used (Table 4). The overall AWW irrigation (50 and $100 \% \mathrm{FC}$ ) effects on the plant-induced denitrification of four plant species were interpreted using principal component analysis (PCA) for the individual parameters. The effects of the irrigation loading rate on $\mathrm{N}$ losses through $\mathrm{N}_{2} \mathrm{O}$ were clearly explained using PCA. The wastewater loading rates $(n=30)$ of both treatments (AWW 100 and $50 \%$ FC) showed distinction from their nutrient loss as $\mathrm{N}_{2} \mathrm{O}$. The AWW with $100 \% \mathrm{FC}$ irrigated pots (all the four plants) greatly varied

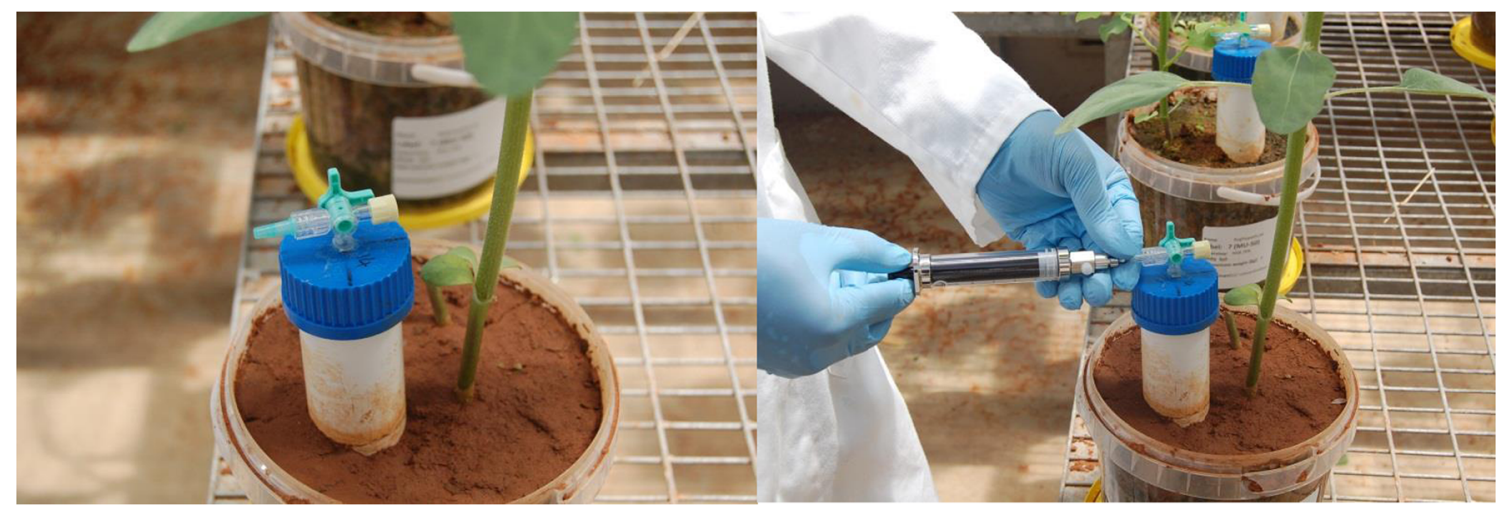

Fig. 6 Nitrous oxide emission from soil irrigated with abattoir wastewater with $100 \%$ FC (moisture gradients) - measured at 4 weeks after planting 
Table 2 Descriptive statistics: the effects of abattoir wastewater irrigation on $\mathrm{N}_{2} \mathrm{O}$ emission: cumulative effects of 50 and $100 \% \mathrm{FC}(n=30)$

\begin{tabular}{lllllllll}
\hline Properties & Range & Minimum & Maximum & Mean & Std. deviation & Variance & Skewness & Kurtosis \\
\hline Nitrate-N (mg/pot) & 621.2 & 291.4 & 912.6 & 489.8 & 193.1 & $37,294.2$ & 0.9 & - \\
Ammonia-N (mg/pot) & 128.0 & 60.0 & 188.0 & 101.1 & 39.9 & 1588.0 & 0.9 & - \\
$\mathrm{N}_{2} \mathrm{O}$ week 1 (mg/pot) & 12.8 & 14.7 & 27.5 & 20.4 & 3.4 & 11.4 & 0.5 & -0.5 \\
$\mathrm{~N}_{2} \mathrm{O}$ week 2 (mg/pot) & 19.9 & 7.6 & 27.5 & 12.4 & 4.5 & 20.3 & 1.8 & 3.4 \\
$\mathrm{~N}_{2} \mathrm{O}$ week 3 (mg/pot) & 18.8 & 3.5 & 22.3 & 12.4 & 5.1 & 26.2 & 0.1 & -1.0 \\
$\mathrm{~N}_{2} \mathrm{O}$ week 4 (mg/pot) & 18.6 & 0.6 & 19.2 & 12.7 & 4.7 & 21.9 & -0.9 & 0.2 \\
Cumulative emission (mg/pot) & 55.8 & 33.0 & 88.8 & 57.9 & 13.9 & 193.9 & 0.1 & -0.5 \\
\hline
\end{tabular}

- equal to zero

from the abattoir $50 \% \mathrm{FC}$ irrigated sample reflecting the quantity of $\mathrm{N}$ loss and their frequency in different time periods. The factor loading float shows clearly the effects of wastewater irrigation on the soil properties.

Similar to a high loading rate, factors 1 (nitrate-N) and 2 (ammonia-N) explained 51 and $21 \%$ of variation, respectively. Therefore, nearly $50 \%$ of the total $\mathrm{N}$ loss as determined by the nutrient load was supplied through wastewater addition. The properties such as ammonia- $\mathrm{N}$ and nitrate- $\mathrm{N}$ were largely influenced (factors 1 and 2) by the overall emission of $\mathrm{N}_{2} \mathrm{O}$. The PCA method showed that AWW irrigation was significantly different in the individual treatments in terms of soil $\mathrm{N}$ loss and DM yield in the current pot experiment. The highest $\mathrm{N}_{2} \mathrm{O}$ emission was recorded at $100 \% \mathrm{FC}$, due to the supply of a high rate of nitrate-N through AWW.

\section{Effects of AWW irrigation on plant-induced denitrification-nutrient loss and utilisation}

This study demonstrated the influence of AWW irrigation on the plant-induced denitrification and soil productivity. The effects of AWW irrigation on soil nutrient loss as $\mathrm{N}_{2} \mathrm{O}$ are presented in Table 5. In the present study, the nutrient input included wastewater- and soil-derived nutrients; the output included plant uptake and loss through $\mathrm{N}_{2} \mathrm{O}$ emission. Using the above information, the percentage of $\mathrm{N}$ loss through $\mathrm{N}_{2} \mathrm{O}$ was calculated to study the effects of AWW irrigation on

Table 3 Effects of abattoir wastewater irrigation on $\mathrm{N}_{2} \mathrm{O}$ emission $(n=30)$; a comparison of cumulative effects of two types of moisture gradient by the two-sample $t$ test

\begin{tabular}{llll}
\hline Properties & $50 \%$ FC & $100 \%$ FC & Sig. diff. \\
\hline $\mathrm{N}_{2} \mathrm{O}$ emitted-week 1 (mg/pot) & $19 \pm 3.1$ & $21.9 \pm 3$ & n.s. \\
$\mathrm{N}_{2} \mathrm{O}$ emitted-week 2 (mg/pot) & $10.2 \pm 2.8$ & $14.6 \pm 4.9$ & $p<0.05$ \\
$\mathrm{~N}_{2} \mathrm{O}$ emitted-week 3 (mg/pot) & $10.1 \pm 4.6$ & $14.7 \pm 4.7$ & n.s. \\
$\mathrm{N}_{2} \mathrm{O}$ emitted-week 4 (mg/pot) & $10 \pm 4.9$ & $15.4 \pm 2.4$ & $p<0.001$ \\
Cumulative emission (mg/pot) & $49.3 \pm 12.5$ & $66.5 \pm 9.3$ & $p<0.001$
\end{tabular}

n.s. not significant plant-induced denitrification, and soil fertility and productivity changes (Eq. 1).

$\%$ of added $\mathrm{N}$ emitted $=\frac{\mathrm{N} \text { emitted }(\mathrm{mg} / \text { pot })}{\mathrm{N} \text { added by AWW }(\mathrm{mg} / \text { pot })} \times 100$

The results from this study showed that $50 \% \mathrm{FC}$ treated soil had higher $\mathrm{N}_{2} \mathrm{O}$ emissions in terms of percentage losses (high differences in input and nutrient loss ratio) compared to the $100 \%$ FC. Similarly, the non-cropped soils were very highly variable between the crops due to the absence of plants. In the current experiment, results showed that nearly 1.2 to $2.4 \%$ of applied $\mathrm{N}$ was lost as $\mathrm{N}_{2} \mathrm{O}$. Moiser et al. (1996) showed that nearly $2.5 \%$ of the total $\mathrm{N}$ applied to the soil was lost as $\mathrm{N}_{2} \mathrm{O}$ from agriculture land. The relationship between $\mathrm{N}$ input and overall $\mathrm{N}_{2} \mathrm{O}$ emission found in this study was positively correlated, similar to the previous research report by IPCC (1999) and studies by Dobbie et al. (1999).

\section{Discussion}

The result from the greenhouse experiments clearly demonstrated that the addition of nutrients or AWW irrigation enhanced the nitrous oxide emission. The effect of nutrient $(\mathrm{N})$ addition on the soil generally increases the soil $\mathrm{N}$ loss through $\mathrm{N}_{2}$ and $\mathrm{N}_{2} \mathrm{O}$, if it is not utilised by green cover, and the excess $\mathrm{N}$ may find a pathway to enter the atmosphere or be leached to groundwater (Reichenau et al. 2016). The following reasons could be attributed to the high nitrous oxide emission from the wastewater-irrigated soils: (i) the rate of nutrient loading through abattoir wastewater irrigation/high soil fertility, (ii) the process of denitrification and (iii) the anaerobic condition created by the excessive addition of abattoir wastewater. The rates of nutrient addition on nitrous oxide emission in soil have been reported by many researchers; for example, Zhang et al. (2016) reported that increased nitrate or phosphate loading resulted in stronger influence on denitrification than single nutrient additions that stimulate denitrification rates in sandy sediments in aquatic/terrestrial transition zones. 
Table 4 Effects of abattoir wastewater irrigation on $\mathrm{N}_{2} \mathrm{O}$ emission $(n=30)$; a comparison of cumulative effects of two types of moisture gradient by Pearson correlation coefficient

\begin{tabular}{|c|c|c|c|c|c|c|c|c|}
\hline Properties & $\begin{array}{l}\text { Nitrate- } \\
\mathrm{N} \\
\text { (mg/pot) }\end{array}$ & $\begin{array}{l}\text { Ammonia- } \\
\mathrm{N} \text { (mg/pot) }\end{array}$ & $\begin{array}{l}\mathrm{N}_{2} \mathrm{O} \text { week } 1 \\
\text { (mg/pot) }\end{array}$ & $\begin{array}{l}\mathrm{N}_{2} \mathrm{O} \text { week } 2 \\
\text { (mg/pot) }\end{array}$ & $\begin{array}{l}\mathrm{N}_{2} \mathrm{O} \text { week } 3 \\
\text { (mg/pot) }\end{array}$ & $\begin{array}{l}\mathrm{N}_{2} \mathrm{O} \text { week } 4 \\
\text { (mg/pot) }\end{array}$ & $\begin{array}{l}\text { Cumulative } \\
\text { emission } \\
\text { (mg/pot) }\end{array}$ & $\begin{array}{l}\text { DM yield } \\
\text { (mg/pot) }\end{array}$ \\
\hline Nitrate-N (mg/pot) & 1 & & & & & & & \\
\hline Ammonia-N (mg/pot) & $0.509 * *$ & 1 & & & & & & \\
\hline $\mathrm{N}_{2} \mathrm{O}$ week 1 (mg/pot) & 0.146 & 0.017 & 1 & & & & & \\
\hline $\mathrm{N}_{2} \mathrm{O}$ week 2 (mg/pot) & 0.348 & 0.035 & $0.655^{* *}$ & 1 & & & & \\
\hline $\mathrm{N}_{2} \mathrm{O}$ week 3 (mg/pot) & 0.252 & 0.159 & $0.432 *$ & 0.255 & 1 & & & \\
\hline $\mathrm{N}_{2} \mathrm{O}$ week 4 (mg/pot) & 0.282 & 0.336 & $0.570 * *$ & $0.620 * *$ & $0.488 * *$ & 1 & & \\
\hline Cumulative emission (mg/pot) & 0.335 & 0.187 & $0.804 * *$ & $0.784 * *$ & $0.719 * *$ & $0.854 * *$ & 1 & \\
\hline DM yield (mg/pot) & -0.076 & -0.246 & $-0.391 *$ & -0.316 & -0.324 & -0.285 & $-0.412 *$ & 1 \\
\hline
\end{tabular}

*Correlation is significant at the 0.05 level; **correlation is significant at the 0.01 level

The abattoir wastewater irrigation had significant impacts on the physiochemical properties of the soils. Nitrous oxide $\left(\mathrm{N}_{2} \mathrm{O}\right)$ emissions can be significantly affected by the amounts of $\mathrm{N}$ available in soils, and also forms of nutrients, local climate and soil conditions are the determining factors of the effects (Peng et al. 2011). Increased $\mathrm{N}$ availability generally leads to increased $\mathrm{N}_{2} \mathrm{O}$ emission (Davidson et al. 1996) because this stimulates the microbial processes of nitrification and denitrification, which produce the gas fluxes. The relationship between $\mathrm{N}$ input ( 500 and $1000 \mathrm{mg} / \mathrm{kg}$ ) on cumulative $\mathrm{N}_{2} \mathrm{O}$ emission found in this study was significant $(\mathrm{N}$ losses increase with the increasing application of N) (Fig. 3). The results have been consistent with earlier reported studies on $\mathrm{N}_{2} \mathrm{O}$ emissions (Liu et al. 2005; van Groenigen et al. 2004; Willén et al. 2016) (Fig. 3). Similarly, Chmura et al. (2016) assessed the impact of nutrient additions on greenhouse gas fluxes using dark static chambers in a microtidal and a macrotidal marsh (Both were experimentally fertilised for 6 years). They found that $\mathrm{N}_{2} \mathrm{O}$ fluxes are likely to vary with the source of pollutant nutrients, but emissions will be lower if $\mathrm{N}$ is not accompanied by an adequate supply of $\mathrm{P}$.

Overall, the application of AWW caused significant $\mathrm{N}_{2} \mathrm{O}$ loss. In our experiment, we compared the two treatments of nutrient loadings $50 \% \mathrm{FC}$ and $100 \% \mathrm{FC}$ and we found that there was a highly significant correlation between both treatments in terms of nitrous oxide emission $(p<0.001)$ (Fig. 4). A number of studies have reported the effect of split fertilisation or low-rate application which showed significant reduction in $\mathrm{N}_{2} \mathrm{O}$ emissions ( $\mathrm{Yu}$ et al. 2016). There was a higher percentage reduction $(28 \%)$ in cumulative $\mathrm{N}_{2} \mathrm{O}$ emissions under the split urea application compared with the single fertilisation, although these emissions were influenced by the $\mathrm{N}$ fertiliser rate and soil moisture (Yu et al. 2016). The results suggest that low-rate application of AWW is a potential strategy for reducing $\mathrm{N}_{2} \mathrm{O}$ emissions in a wastewater-irrigated soil or in a land treatment site. Similarly, the results by Neto et al. (2016) showed that $\mathrm{N}$ fertiliser increased $\mathrm{N}_{2} \mathrm{O}$ emissions from the soil, especially when urea was used. The emission factor for $\mathrm{N}$ fertiliser was $0.46 \pm 0.33 \%$.

There was no difference between urea fertiliser and abattoir wastewater nutrient addition on nitrous oxide emission values. Values of $\mathrm{N}_{2} \mathrm{O}$ fluxes were reported for each week and compared with cumulative emission. The application of AWW at the rate of $100 \% \mathrm{FC}$ reached a peak of $24 \mathrm{mg} /$ pot emission in the first few weeks after planting (Fig. 5). A study by van der Weerden et al. (2016) recommended an $\mathrm{N}_{2} \mathrm{O}$ emission inventory for New Zealand's agricultural soils and found that there was no difference between urea fertiliser in terms of $\mathrm{N}_{2} \mathrm{O}$

Table 5 Effects of abattoir wastewater irrigation on $\mathrm{N}$ loss as $\mathrm{N}_{2} \mathrm{O}$ emission (\%) in two types of loading rate in four crops grown under greenhouse condition $(n=30)$

\begin{tabular}{|c|c|c|c|c|c|c|c|c|}
\hline \multirow[t]{2}{*}{ Crops } & \multicolumn{2}{|c|}{$\mathrm{N}$ added through effluent (mg/pot) } & \multicolumn{2}{|c|}{$\mathrm{N}$ emitted (mg/pot) } & \multicolumn{2}{|c|}{$\%$ of $\mathrm{N}$ emitted } & \multicolumn{2}{|c|}{ DM yield (mg/pot) } \\
\hline & $50 \% \mathrm{FC}$ & $100 \% \mathrm{FC}$ & $50 \% \mathrm{FC}$ & $100 \% \mathrm{FC}$ & $50 \% \mathrm{FC}$ & $100 \% \mathrm{FC}$ & $50 \% \mathrm{FC}$ & $100 \% \mathrm{FC}$ \\
\hline Alfalfa & 973.2 & 2031.9 & 17.6 & 23.0 & 1.8 & 1.1 & 7333.3 & 9333.3 \\
\hline Mustard & 973.2 & 2031.9 & 17.8 & 21.9 & 1.8 & 1.1 & $14,333.3$ & $16,666.7$ \\
\hline Maize & 973.2 & 2031.9 & 18.2 & 20.8 & 1.9 & 1.0 & $24,666.7$ & $32,666.7$ \\
\hline Sunflower & 973.2 & 2031.9 & 18.2 & 20.3 & 1.9 & 1.0 & $28,666.7$ & $39,333.3$ \\
\hline No crop & 973.2 & 2031.9 & 23.0 & 23.4 & 2.4 & 1.2 & 0 & 0 \\
\hline
\end{tabular}


emission due to the different origins and characteristics of these $\mathrm{N}$ sources. For example, in New Zealand's agricultural soils, $\mathrm{N}_{2} \mathrm{O}$ emissions have means of 0.6 and $0.3 \%$ for urea fertiliser and FDE, respectively (der Weerden et al. 2016).

According to a study report by Rowe et al. (2012), the effect of $\mathrm{N}$ deposition on mineralisable $\mathrm{N}$ stock was more apparent in more organic soils, whereas the effect on nitrate proportion was more apparent in more mineral soils. With the high proportions of nitrate (over $40 \%$ ) that responses also depend on soil $\mathrm{C}$ content and site temperature (Table 1). The proportions of mineral $\mathrm{N}$ and nitrate were both strongly influenced by the $\mathrm{N}$ deposition rate and by interactions with soil $\mathrm{C}$ content (Rowe et al. 2012). In soil, urea is rapidly hydrolysed to ammonium $\left(\mathrm{NH}_{4}{ }^{+}\right)$ ions, a part of which may be lost as ammonia $\left(\mathrm{NH}_{3}{ }^{-}\right)$and subsequently as nitrous oxide $\left(\mathrm{N}_{2} \mathrm{O}\right)$ (Singh et al. 2013). The rate of denitrification was higher in soils incubated at saturation than in soils incubated at FC. Brown et al. (2012) found that denitrification was the dominant microbial source of $\mathrm{N}_{2} \mathrm{O}$, and responded to increased soil water content and higher labile carbon availability. Elevated precipitation increased soil emissions of $\mathrm{N}_{2} \mathrm{O}$, especially in combination with added nitrogen and heat. The reduction to $\mathrm{N}_{2}$ plus absorption by water primarily depends on soil properties, such as the availability of mineral $\mathrm{N}$ (substrate for nitrification and denitrification), soil oxygen and water content, soil temperature, $\mathrm{pH}$ and redox conditions, and the availability of labile organic C and N (Chapuis et al. 2007; Yan et al. 2012). Urease inhibitor increased the plant $\mathrm{N}$ uptake but did not result in a significant increase in herbage DM yields from urea fertiliser. Urease inhibitor was effective in reducing $\mathrm{NH}_{3}{ }^{-}$and $\mathrm{N}_{2} \mathrm{O}$ emissions from both the urine and urea treatments, with the reduction in $\mathrm{N}_{2} \mathrm{O}$ emissions varying with plant $\mathrm{N}$ uptake (Singh et al. 2013). However, the effect of changing soil moisture on DR and $\mathrm{N}_{2} \mathrm{O} / \mathrm{N}_{2}$ ratio may vary with the type of soil, its nutrient status and the management practices followed on the farm (Jha et al. 2012).

At wastewater irrigation sites, nitrate is formed during the irrigation events. The soil air is rapidly displaced by the wastewater and the soil becomes saturated. Denitrification and nitrous oxide emission rates are at a maximum during this period. As the site drains, the number of anoxic sites decreases and background rates re-establish (Russell et al. 1993). Peng et al. (2011) observed that peak $\mathrm{N}_{2} \mathrm{O}$ fluxes induced by $\mathrm{N}$ treatments were concentrated in short periods ( 2 to 3 weeks) after fertilisation in summer and in soil thawing periods in early spring. The weekly $\mathrm{N}_{2} \mathrm{O}$ emission was calculated for each crop, and we found significant differences among the crops used with two levels of AWW irrigation. Overall, the $\mathrm{N}_{2} \mathrm{O}$ fluxes were significantly higher in $100 \%$ FC compared to $50 \%$ FC (Fig. 6) probably due to a larger amount of AWW irrigation with nutrients (Table 1). The three $\mathrm{N}$ levels increased annual $\mathrm{N}_{2} \mathrm{O}$ emissions significantly $(P<0.05)$ in the medium and high $\mathrm{N}$ loading treatments compared with the control. A similar pattern was reported by Russell et al. (1993) in which peak rates at the pasture sites were higher with primary-treated effluent (1-137 $\mathrm{g} \mathrm{N}_{2} \mathrm{O}$ $\mathrm{N}$ ha/h) than with anaerobic effluent ( $1-62 \mathrm{~g} \mathrm{~N} \mathrm{~N}_{2} \mathrm{O}-\mathrm{N}$ ha/h). This was attributed to the higher organic carbon concentration in primary-treated effluent and possibly soil temperature peak nitrous oxide emission rates increased with increasing surface soil temperature. A study by Bhandral et al. (2007) found that among the $\mathrm{N}$ sources, the highest emissions were measured with nitrate application, emissions being ten times more than those from other $\mathrm{N}$ sources for compacted soil. Also, they reported that the soil compaction caused a sevenfold increase in the $\mathrm{N}_{2} \mathrm{O}$ flux; the total $\mathrm{N}_{2} \mathrm{O}$ fluxes for the entire experimental period ranged from 2.62 to $61.74 \mathrm{~kg} \mathrm{~N} \mathrm{~N}_{2} \mathrm{O}-\mathrm{N} / \mathrm{ha}$ for the compacted soil and 1.12 to $4.37 \mathrm{~kg} \mathrm{~N}_{2} \mathrm{O}-\mathrm{N} / \mathrm{ha}$ for the uncompacted soil.

The $\mathrm{N}_{2} \mathrm{O}$ emissions were very low in pots with high DM yield as found in this study and shown in Table 5, possibly due to a high amount of nutrient uptake by the crops for growth and development. On the other hand, not-cropped conditions show a higher nutrient loss (high $\mathrm{N}_{2} \mathrm{O}$ emission fluxes recorded in this study) (Table 5). The increased $\mathrm{N}_{2} \mathrm{O}$ emission from the control pot was due to the absence of crop or nutrient utilisation by crops. A twofold increase in the $\mathrm{N}_{2} \mathrm{O}$ emission rate was recorded for the non-cropped pot compared to the cropped pot. In this short-duration study, major peaks were observed on the first 2 weeks after the treatment including the cropped and non-cropped control; this might have continued to increase for a few weeks after the treatment if we continued to irrigate the field at the same irrigation rate (Bhandral et al. 2007). Soils are the main sources of the greenhouse gas $\mathrm{N}_{2} \mathrm{O}$. The $\mathrm{N}_{2} \mathrm{O}$ emission at the soil surface is the result of production and consumption processes of agricultural systems (Chapuis et al. 2007).

In grazed pastures, loss of $\mathrm{N}$ occurs mainly through ammonia $\left(\mathrm{NH}_{3}{ }^{-}\right)$volatilisation, the release of gaseous $\mathrm{N}$ such as nitric oxide (NO) and nitrous oxide $\left(\mathrm{N}_{2} \mathrm{O}\right)$ through biological denitrification, and nitrate $\left(\mathrm{NO}_{3}{ }^{-}\right)$leaching, which has both economic and environmental implications (Bolan et al. 2004). In the nearly water-saturated soil (90 \% WFPS), $\mathrm{N}_{2} \mathrm{O}$ production was, as expected, dominated by conventional denitrification of $\mathrm{NO}_{3}{ }^{-}$ (Kool et al. 2011). A similar result was reported by Weitz et al. (2001) and Zhou et al. (2008) that $\mathrm{N}_{2} \mathrm{O}$ emission was insensitive to soil moisture, possibly resulting from lower soil nitrogen content $(0.13-0.21 \%)$. Differences were observed in nitrification-denitrification rates in flooding conditions because they control the availability of $\mathrm{N}$ and oxygen. Nitrification was controlled not only by oxygen but also by the amount of ammonium sulphate added and the high $\mathrm{pH}$ of the water; these two latter factors could increase the $\mathrm{NH}_{3}$ concentration, with inhibition of the coupled nitrification-denitrification (Carrasco et al. 2004). The results of Bateman and Baggs (2005) indicate $\mathrm{N}_{2} \mathrm{O}$ production during heterotrophic nitrification in our soil at $50 \%$ WFPS and the possibility of aerobic denitrification. Thus, several processes may simultaneously produce $\mathrm{N}_{2} \mathrm{O}$ in soil at 
$60 \%$ WFPS and below. Nitrification was the main source of $\mathrm{N}_{2} \mathrm{O}$ in soils at 35-60\% WFPS, indicating the significance of this process for global warming.

\section{Conclusions}

A nutrient-rich water source (e.g. AWW) can supply sufficient or a surplus amount of primary nutrients to the soil and plants. However, a significant amount of applied nutrient $(\mathrm{N})$ is lost to air, soil and water through various processes by $\mathrm{N}_{2} \mathrm{O}$ and ammonia $\left(\mathrm{NH}_{3}\right)$ emissions and nitrate leaching. These losses are considered environmental hazards due to the ill effects caused by $\mathrm{N}_{2} \mathrm{O}$ as a potential greenhouse gas and nitrate in groundwater as a potential water pollutant. Hence, minimising and management of nitrogenous pollutants become more important in the current era of sustainable agriculture. The mitigation options to reduce $\mathrm{N}$ loss include the use of nitrogenous inhibitors (NI), growing bioenergy crops and adopting efficient farm budgeting (applying nutrients only when it is necessary). The emission of nitrous oxide was high at the first 2 weeks after planting and declined subsequently reaching the background levels within 4 weeks. Nitrous oxide emission was higher for $100 \% \mathrm{FC}$ than for $50 \% \mathrm{FC}$. The peak nitrous oxide emission flux was recorded in the non-cropping condition during the first week after planting; this indicated that there are higher risks of applied nitrogen loss through nitrous oxide emission in the absence of plant uptake of nitrogen. Overall, nitrous oxide emission was $15 \%$ higher in the noncropped than cropped treatments. The conclusions that can be drawn from this study in relation to plant-induced denitrification are as follows: the $\mathrm{N}_{2} \mathrm{O}$ emission rate increased with increasing soil moisture content (50 to $100 \%$ FC), the $\mathrm{N}_{2} \mathrm{O}$ emission rate increased with increasing $\mathrm{N}$ input through chemical fertiliser or wastewater irrigation, the $\mathrm{N}_{2} \mathrm{O}$ emission rate decreased in the presence of plants and increased under the no-crop condition due to plant uptake and dry matter yield was found to be significantly higher in the $100 \% \mathrm{FC}$ than the $50 \%$ treatment. The rate of $\mathrm{N}$ loss varied with the rate of $\mathrm{AWW}$ irrigation; nearly 1.2 to $2.4 \%$ of applied $\mathrm{N}$ was lost as $\mathrm{N}_{2} \mathrm{O}$. The main conclusions that can be drawn from this study in relation to plant-induced denitrification are the following: the $\mathrm{N}_{2} \mathrm{O}$ emission rate increased with increasing soil moisture content, the $\mathrm{N}_{2} \mathrm{O}$ emission rate increased with increasing $\mathrm{N}$ input through wastewater irrigation and the $\mathrm{N}_{2} \mathrm{O}$ emission rate decreased with the presence of plants which can be attributed to plant uptake.

Acknowledgments The first author would like to thank the University of South Australia for the UPS scholarships and CRC for Contamination Assessment and Remediation of the Environment for the CRC-CARE scholarships to undertake research on nutrient management in abattoir wastewater-discharged soil.
Open Access This article is distributed under the terms of the Creative Commons Attribution 4.0 International License (http:// creativecommons.org/licenses/by/4.0/), which permits unrestricted use, distribution, and reproduction in any medium, provided you give appropriate credit to the original author(s) and the source, provide a link to the Creative Commons license, and indicate if changes were made.

\section{References}

Aulakh MS, Khera TS, Doran JW, Bronson KF (2001) Denitrification, $\mathrm{N}_{2} \mathrm{O}$ and $\mathrm{CO}_{2}$ fluxes in rice-wheat cropping system as affected by crop residues, fertilizer $\mathrm{N}$ and legume green manure. Biol Fertil Soils 34:375-389

Bateman E, Baggs E (2005) Contributions of nitrification and denitrification to $\mathrm{N}_{2} \mathrm{O}$ emissions from soils at different water-filled pore space. Biol Fertil Soils 41:379-388

Baumert KA, Herzog T, Pershing J (2005) Navigating the numbers: greenhouse gas data and international climate policy. World Resour Inst

Bhandral R, Saggar S, Bolan N, Hedley M (2007) Transformation of nitrogen and nitrous oxide emission from grassland soils as affected by compaction. Soil Tillage Res 94:482-492

Bolan NS, Saggar S, Luo J, Bhandral R, Singh J (2004) Gaseous emissions of nitrogen from grazed pastures: processes, measurements and modelling, environmental implications, and mitigation. Adv Agron 84:37-120

Bouwman A (1996) Direct emission of nitrous oxide from agricultural soils. Nutr Cycl Agroecosyst 46:53-70

Brown JR et al. (2012) Effects of multiple global change treatments on soil $\mathrm{N}_{2} \mathrm{O}$ fluxes. Biogeochemistry 109:85-100

Cardenas L, Thorman R, Ashlee N, Butler M, Chadwick D, Chambers B, Cuttle S, Donovan N, Kingston H, Lane S (2010) Quantifying annual $\mathrm{N} 2 \mathrm{O}$ emission fluxes from grazed grassland under a range of inorganic fertiliser nitrogen inputs. Agric Ecosyst Environ 136:218-226

Carrasco D, Fernández-Valiente E, Ariosa Y, Quesada A (2004) Measurement of coupled nitrification-denitrification in paddy fields affected by Terrazole, a nitrification inhibitor. Biol Fertil Soils 39: 186-192

Cassidy DP, Belia E (2005) Nitrogen and phosphorus removal from an abattoir wastewater in a SBR with aerobic granular sludge. Water Res 39:4817-4823. doi:10.1016/j.watres.2005.09.025

Cerri CC, Maia SM, Galdos MV, Cerri CE, Feigl BJ, Bernoux M (2009) Brazilian greenhouse gas emissions: the importance of agriculture and livestock. Scientia Agricola 66(6):831-843

Chapuis-Lardy L, Wrage N, Metay A, JL CHOTTE, Bernoux M (2007) Soils, a sink for $\mathrm{N}_{2} \mathrm{O}$ ? A review. Glob Chang Biol 13:1-17

Chen M, Ma LQ (2001) Comparison of three aqua regia digestion methods for twenty Florida soils. Soil Sci Soc Am J 65:491-499

Chmura GL, Kellman L, van Ardenne L, Guntenspergen GR (2016) Greenhouse gas fluxes from salt marshes exposed to chronic nutrient enrichment. PLoS One 11:e0149937

Crutzen PJ, Mosier AR, Smith KA, Winiwarter W (2008) N2O release from agro-biofuel production negates global warming reduction by replacing fossil fuels. Atmos Chem Phys 8:389-395

Czepiel P, Crill P, Harriss R (1995) Nitrous oxide emissions from municipal wastewater treatment. Environ Sci Technol 29:2352-2356

Dalal RC, Wang W, Robertson GP, Parton WJ (2003) Nitrous oxide emission from Australian agricultural lands and mitigation options: a review. Soil Res 41:165-195

Davidson E, Matson PA, Brooks P (1996) Nitrous oxide emission controls and inorganic nitrogen dynamics in fertilized tropical agricultural soils. Soil Sci Soc Am J 60:1145-1152 
Dobbie K, McTaggart I, Smith K (1999) Nitrous oxide emissions from intensive agricultural systems: variations between crops and seasons, key driving variables, and mean emission factors. J Geophys Res Atmos 104:26891-26899

Food and Agriculture Organisation (FAO) (2006) Livestock's long shadow-environmental issues and option www.fao.org

Garnaut R, Howes S, Jotzo F, Sheehan P (2008) Emissions in the Platinum Age: the implications of rapid development for climatechange mitigation. Oxf Rev Econ Policy 20;24(2):377-401

Gunnarsson I, Sigfússon B, Stefánsson A, Arnórsson S, Scott SW, Gunnlaugsson E (2011) Injection of H2S from Hellisheiði Power Plant, Iceland. In: Proceedings of the 36th Workshop on Geothermal Reservoir Engineering

Intergovernmental Panel on Climate Change (IPCC) (1999) Climate Change 2001 - The Scientific Basis. Contributions of working group I to the Third Assessment Report of the Intergovernmental Panel on Climate Change. Cambridge University Press, Cambridge, UK and New York, NY, USA, p 881

Intergovernmental Panel on Climate Change (IPCC) (2007). IPCC Secretariat Geneva www.ipcc.ch

Jha N, Saggar S, Tillman R, Giltrap D (2012) Changes in denitrification rate and $\mathrm{N}_{2} \mathrm{O} / \mathrm{N}_{2}$ ratio with varying soil moisture conditions of New Zealand pasture soils. Advanced nutrient management: gains from the past-goals for the future. Fertilizer and Lime Research Centre Occasional Report

Kampschreur MJ, Tan NC, Kleerebezem R, Picioreanu C, Jetten MS, Loosdrecht MCV (2007) Effect of dynamic process conditions on nitrogen oxides emission from a nitrifying culture. Environ Sci Technol 42:429-435

Kampschreur MJ, Temmink H, Kleerebezem R, Jetten MS, van Loosdrecht MC (2009) Nitrous oxide emission during wastewater treatment. Water Res 43:4093-4103

Kiese R, Butterbach-Bahl K (2002) $\mathrm{N}_{2} \mathrm{O}$ and $\mathrm{CO}_{2}$ emissions from three different tropical forest sites in the wet tropics of Queensland, Australia. Soil Biol Biochem 34:975-987

Kool DM, Dolfing J, Wrage N, Van Groenigen JW (2011) Nitrifier denitrification as a distinct and significant source of nitrous oxide from soil. Soil Biol Biochem 43:174-178

Liu XJ, Mosier AR, Halvorson AD, Zhang FS (2005) Tillage and nitrogen application effects on nitrous and nitric oxide emissions from irrigated corn fields. Plant Soil 276:235-249

Longhurst R, Roberts A, O'Connor M (2000) Farm dairy effluent: a review of published data on chemical and physical characteristics in New Zealand. N Z J Agric Res 43:7-14

Luo J, Lindsey S, Xue J (2004) Irrigation of meat processing wastewater onto land. Agric Ecosyst Environ 103:123-148

Maag M, Vinther FP (1996) Nitrous oxide emission by nitrification and denitrification in different soil types and at different soil moisture contents and temperatures. Appl Soil Ecol 4:5-14

Matheyarasu R, Seshadri B, Bolan N, Naidu R (2012) Nutrient management in effluents derived from agricultural industries: an Australian perspective. WIT Press

Matheyarasu R, Seshadri B, Bolan NS, Naidu R (2014) Impacts of abattoir waste-water irrigation on soil fertility and productivity

McCarl BA, Schneider UA (2000) US agriculture's role in a greenhouse gas emission mitigation world: an economic perspective. Rev Agric Econ 22:134-159

Meinshausen M, Meinshausen N, Hare W, Raper SC, Frieler K, Knutti R, Frame DJ, Allen MR (2009) Greenhouse-gas emission targets for limiting global warming to $2 \mathrm{C}$. Nature 458(7242):1158-1162

Meat \& Livestock Australia (MLA) (2010) Industry environmental sustainability review A.ENV.0086

Mosier A, Parton W, Valentine D, Ojima D, Schimel D, Delgado J (1996) $\mathrm{CH} 4$ and $\mathrm{N}_{2} \mathrm{O}$ fluxes in the Colorado shortgrass steppe: 1. Impact of landscape and nitrogen addition. Glob Biogeochem Cycles 10:387-399
Oenema O, Wrage N, Velthof GL, van Groenigen JW, Dolfing J, Kuikman PJ (2005) Trends in global nitrous oxide emissions from animal production systems. Nutr Cycl Agroecosyst 72: $51-65$

Olsen SR, Cole CV, Watanabe FS, Dean LA (1954) Estimation of available phosphorus in soils by extraction with sodium bicarbonate. US Dep Agric Circ 939

Organisation for Economic Co-operation and Development (OECD) FAO (2011) Agricultural Outlook 2011-2020 OECD-FAO:14

Peng Q, Qi Y, Dong Y, Xiao S, He Y (2011) Soil nitrous oxide emissions from a typical semiarid temperate steppe in inner Mongolia: effects of mineral nitrogen fertilizer levels and forms. Plant Soil 342:345-357

Preston BL, Jones RN, Scientific C (2006) Climate change impacts on Australia and the benefits of early action to reduce global greenhouse gas emissions. CSIRO Australia

Ravishankara A, Daniel JS, Portmann RW (2009) Nitrous oxide $\left(\mathrm{N}_{2} \mathrm{O}\right)$ : the dominant ozone-depleting substance emitted in the 21 st century. Science 326:123-125

Rayment GE, Lyons DJ (2011) Soil chemical methods: Australasia vol 3. CSIRO publishing

Reichenau TG, Klar CW, Lenz-Wiedemann VI, Fiener P, Schneider K, (2016) Nitrate leaching, regional assessment of global change impacts. Springer, pp. 303-310

Rowe EC, Emmett BA, Frogbrook ZL, Robinson DA, Hughes S (2012) Nitrogen deposition and climate effects on soil nitrogen availability: influences of habitat type and soil characteristics. Sci Total Environ 434:62-70

Russell J, Cooper R, Lindsey S (1993) Soil denitrification rates at wastewater irrigation sites receiving primary-treated and anaerobically treated meat-processing effluent. Bioresour Technol 43:41-46

Saggar S, Andrew R, Tate K, Rodda N, Hedley C, Townsend J (2002) Measurements and modelling of nitrous oxide emissions from dairy pastures. In: Currie LD, Loganathan P (eds) Proceedings of the workshop on dairy farm soil management. Massey University, Palmerston North, pp. 201-214

Saggar S, Bolan N, Bhandral R, Hedley C, Luo J (2004) A review of emissions of methane, ammonia, and nitrous oxide from animal excreta deposition and farm effluent application in grazed pastures. N Z J Agric Res 47:513-544

Saggar $\mathrm{S}$ et al. (2013) Denitrification and $\mathrm{N}_{2} \mathrm{O}: \mathrm{N}_{2}$ production in temperate grasslands: processes, measurements, modelling and mitigating negative impacts. Sci Total Environ 465:173-195

Saggar S, Giltrap DL, Davison R, Gibson R, de Klein CA, Rollo M, Ettema P, Rys $\mathrm{G}$ (2015) Estimating direct $\mathrm{N}_{2} \mathrm{O}$ emissions from sheep, beef, and deer grazed pastures in New Zealand hill country: accounting for the effect of land slope on the $\mathrm{N}_{2} \mathrm{O}$ emission factors from urine and dung. Agric Ecosyst Environ 205:70-78

Schneider UA (2000) Agricultural sector analysis on greenhouse gas emission mitigation in the United States. Texas A\&M University

Shine KP, Fuglestvedt JS, Hailemariam K, Stuber N (2005) Alternatives to the global warming potential for comparing climate impacts of emissions of greenhouse gases. Clim Chang 68:281-302

Singh J, Saggar S, Giltrap D, Bolan NS (2008) Decomposition of dicyandiamide (DCD) in three contrasting soils and its effect on nitrous oxide emission, soil respiratory activity, and microbial biomass - an incubation study. Soil Res 46:517-525

Singh J, Kunhikrishnan A, Bolan NS, Saggar S (2013) Impact of urease inhibitor on ammonia and nitrous oxide emissions from temperate pasture soil cores receiving urea fertilizer and cattle urine. Sci total Environ 465:56-63

Siqueira Neto M, Galdos MV, Feigl BJ, Cerri CE, Cerri CC (2016) Direct $\mathrm{N} 2 \mathrm{O}$ emission factors for synthetic $\mathrm{N}$-fertilizer and organic residues applied on sugarcane for bioethanol production in central-southern Brazil. GCB Bioenergy 8:269-280 
Sparling G et al. (2006) Nutrient leaching and changes in soil characteristics of four contrasting soils irrigated with secondary-treated municipal wastewater for four years. Soil Res 44:107-116

Tsujimoto Y, Masuda J, Fukuyama J, Ito $\mathrm{H}$ (1994) $\mathrm{N}_{2} \mathrm{O}$ emissions at solid waste disposal sites in Osaka City. Air Waste 44:1313-1314

van der Weerden T, Cox N, Luo J, Di H, Podolyan A, Phillips R, Saggar S, de Klein C, Ettema P, Rys G (2016) Refining the New Zealand nitrous oxide emission factor for urea fertiliser and farm dairy effluent. Agric Ecosyst Environ 222:133-137

van Groenigen JW, Kasper GJ, Velthof GL, van den Pol-van Dasselaar A, Kuikman PJ (2004) Nitrous oxide emissions from silage maize fields under different mineral nitrogen fertilizer and slurry applications. Plant Soil 263:101-111

Weier KL, Doran JW, Power JF, Walters DT (1993) Denitrification and the dinitrogen/nitrous oxide ratio as affected by soil water, available carbon, and nitrate. Soil Sci Soc Am J 57(1):66-72

Weitz A, Linder E, Frolking S, Crill P, Keller M (2001) $\mathrm{N}_{2} \mathrm{O}$ emissions from humid tropical agricultural soils: effects of soil moisture, texture and nitrogen availability. Soil Biol Biochem 33:1077-1093
Willén A, Jönsson H, Pell M, Rodhe L (2016) Emissions of nitrous oxide, methane and ammonia after field application of digested and dewatered sewage sludge with or without addition of urea. Waste Biomass Valorization 7:281-292

Yan C, Zhang H, Li B, Wang D, Zhao Y, Zheng Z (2012) Effects of influent $\mathrm{C} / \mathrm{N}$ ratios on $\mathrm{CO} 2$ and $\mathrm{CH} 4$ emissions from vertical subsurface flow constructed wetlands treating synthetic municipal wastewater. J Hazard Mater 203:188-194

Yu Y, Zhao C, Jia H (2016) Ability of split urea applications to reduce nitrous oxide emissions: a laboratory incubation experiment. Appl Soil Ecol 100:75-80

Zhang L, Yao X, Tang C, Xu H, Jiang X, Zhang Y (2016) Influence of long-term inundation and nutrient addition on denitrification in sandy wetland sediments from Poyang Lake, a large shallow subtropical lake in China. Environ Pollut

Zhou YA, Pijuan M, Zeng RJ, Yuan Z (2008) Free nitrous acid inhibition on nitrous oxide reduction by a denitrifying-enhanced biological phosphorus removal sludge. Environ Sci Technol 42(22):8260 8265 